\title{
RECENT THERMOCHEMICAL RESEARCH ON REACTOR MATERIALS AND FISSION PRODUCTS
}

\author{
E.H.P. CORDFUNKE and R.J.M. KONINGS \\ Netherlands Energy Research Foundation ECN, P.O. Box 1, 1755 ZG Petten, The Netherlands \\ E.F. WESTRUM, Jr. \\ Department of Chemistry, The University of Michigan, Ann Arbor, MI 48109, USA
}

\begin{abstract}
By adiabatic calorimetric measurements from 5 to $350 \mathrm{~K}$ and enthalpy increment determinations above the ambient temperature the thermophysical properties of such uranium compounds as $\mathrm{UF}_{3}, \mathrm{UCl}_{3}, \mathrm{UBr}_{3}, \mathrm{URu}_{3}, \mathrm{URh}_{3}, \mathrm{UPd}_{3}$ and fission product combinations such as $\mathrm{RuO}_{2}, \mathrm{RuSe}_{2}$, and $\mathrm{CsBO}_{2}$ have been obtained. In addition, the enthalpies of formation of these substances have been determined by EMF and enthalpy of solution measurements. By combining these measurements the formation properties have been derived as a basis for modeling, critical evaluation and prediction. Some examples of these applications are given.
\end{abstract}

\section{Introduction}

It was emphasized by F.D. Rossini in 1963 that " the requirements of basic science for pioneering investigations and of applied science for industrial processes were calling for (thermochemical) data of increasing accuracy" [1]. This general statement is particularly true for the vast arca of nuclear technology where complex chemical processes occur in all stages of the fuel cycle. Especially the phenomena that can occur in the course of a nuclear reactor accident are complex because many chemical species and environments are involved.

Computer models are currently being used to calculate the chemical equilibria in reactor accidents as a function of temperature and time in order to understand and to predict these chemical phenomena. It is evident that the results of such an analysis depend on the availability and accuracy of the thermodynamic data used in the calculations. It has been pointed out before [2] that the current thermochemical data base for these calculations is still poor and that for many compounds, in particular at high temperatures $(>1000 \mathrm{~K})$, estimated values have to be used.

The collaboration of the present authors from ECN (Petten) and the University of Michigan (Ann Arbor) over a long period of time has resulted in the accurate experimental determination of the thermodynamic propertics of a number of reactor materials and fission product compounds. In this paper we present some of our recent results with emphasis on the application of the data in nuclear technology. Although the main thrust has been the collection of accurate experimental data, a complementary goal has been to provide the means for the estimation of data in the absence of measurements.

\section{Experimental}

The measurements described below were done partly in Ann Arbor and partly in Petten using the same well-characterized and analysed samples which were prepared in Petten.

The low-temperature heat capacity measurements have been made in Ann Arbor in a computer-driven, adiabatic calorimetric cryostat with the necessary calibrations, as described elsewhere [3]. The enthalpy measurements above $298.15 \mathrm{~K}$ were done in Petten in an isothermal diphenyl-ether drop calorimeter, which has been calibrated with $\alpha-\mathrm{SiO}_{2}$, and compared with the NBS standard reference material synthetic sapphire, $\mathrm{Al}_{2} \mathrm{O}_{3}$ (No. 720) [4]. The consistency between the lowtemperature heat capacity data and the high-temperature enthalpy increments is checked by a graphical presentation of the two sets of measurements in a plot of $\left\{H^{\circ}(T)-H^{\circ}(298.15 \mathrm{~K})\right\} /(T-298.15 \mathrm{~K})$ against $T$. This function equals $C_{\mathrm{p}}^{\circ}$ at $298.15 \mathrm{~K}$ and should give 
a smooth conncetion betwcen the low- and high-temperature data.

Enthalpies of solution, measured calorimetrically [5], and EMF measurements [6] were used to derive enthalpies of formation. The following notations have been made throughout this paper:

$C_{\mathrm{p}}^{\circ}=$ standard heat capacity $\left(\mathrm{J} \mathrm{mol}^{-1} \mathrm{~K}^{-1}\right)$,

$S^{\circ}=$ standard entropy $\left(\mathrm{J} \mathrm{mol}^{-1} \mathrm{~K}^{-1}\right)$,

$\Delta_{\mathrm{f}} H^{\circ}=$ standard enthalpy of formation $\left(\mathrm{kJ} \mathrm{mol}{ }^{-1}\right)$,

$\Delta_{\mathrm{f}} G^{\circ}=$ standard Gibbs energy of formation $\left(\mathrm{kJ} \mathrm{mol}^{-1}\right)$.

\section{Uranium thrihalides}

Although the uranium fluorides are important materials in the various parts of the fuel cycle, thermodynamic data of $U_{3}$ are still incomplete and inconsistent. For instance and remarkably, heat-capacity values have not been published before. Our measurements of the low-temperature heat-capacity values of $\mathrm{UF}_{3}$ smoothly join the enthalpy increment data $(398-866 \mathrm{~K})$ [7] and we derive:

$$
\begin{aligned}
& C_{\mathrm{p}}^{\circ}(198.15 \mathrm{~K})=95.10 \mathrm{~J} \mathrm{~mol}^{-1} \mathrm{~K}^{-1} \\
& S^{\circ}(298.15 \mathrm{~K})=(123.46 \pm 0.5) \mathrm{J} \mathrm{mol}^{-1} \mathrm{~K}^{-1} \\
& \left\{H^{\circ}(T)-H^{\circ}(298.15 \mathrm{~K})\right\} / \mathrm{J} \mathrm{mol}{ }^{-1} \\
& =106.541(T / \mathrm{K})+35.271 \times 10^{-3}(T / \mathrm{K})^{2} \\
& \quad+10.355 \times 10^{5}(T / \mathrm{K})^{-1}-35269.0
\end{aligned}
$$

In order to evaluate the Gibbs energy of formation of $\mathrm{UF}_{3}(\mathrm{~s})$ we need the enthalpy of formation. This quantity has been assessed by Fuger et al. [8] from a number of different measurements. We here accept their assessed value, $\Delta_{\mathrm{f}} H^{\circ}(298.15 \mathrm{~K})=-(1502.1 \pm 5.0) \mathrm{kJ}$ $\mathrm{mol}^{-1}$, and refer for their arguments to the original publication. Values of $\Delta_{f} G^{\circ}(T)$ for $\mathrm{UF}_{3}(\mathrm{~s})$ have been listed in table 1.

The chlorides of uranium have not played as prominent a role in nuclear technology as have the fluorides. However, in the metallic-fueled fast breeder reactor, which is now being developed in the USA, $\mathrm{UCl}_{3}$ is used in the on-site fuel re-processing by pyrochemical processes [9]. Metallic fuel is first dissolved (after oxidation) into a molten salt solvent, and subsequently separated from the molten salt (after reduction):

$\mathrm{UCl}_{3}($ soln $)+\frac{3}{2} \mathrm{Mg}$ (alloy) $\rightarrow \mathrm{U}($ alloy $)+\frac{3}{2} \mathrm{MgCl}_{2}$ (soln $)$.

The distribution coefficient of uranium can be calculated when $\Delta_{\mathrm{f}} G^{\circ}\left(\mathrm{UCl}_{3}\right)$ is known with sufficient accuracy.

Again, thermodynamic properties of $\mathrm{UCl}_{3}$ are poorly known. Heat capacity measurements on a pure sample of $\mathrm{UCl}_{3}$ (fig. 1) have given the values [7]:

$$
\begin{aligned}
& C_{\mathrm{p}}^{\circ}(298.15 \mathrm{~K})=102.52 \mathrm{~J} \mathrm{~mol}^{-1} \mathrm{~K}^{-1}, \\
& S^{\circ}(298.15 \mathrm{~K})=158.14 \mathrm{~J} \mathrm{~mol}^{-1} \mathrm{~K}^{-1} .
\end{aligned}
$$

\begin{tabular}{|c|c|c|c|c|c|c|c|c|c|c|c|}
\hline$T(\overline{\mathbf{K}})$ & $\mathrm{UF}_{3}$ & $\mathrm{UCl}_{3}$ & $\mathrm{UBr}_{3}$ & $\mathrm{URu}_{3}$ & $\mathrm{URh}_{3}$ & $\mathrm{UPd}_{3}$ & $\mathrm{RuO}_{2}$ & $\mathrm{RuSe}_{2}$ & $\overline{\mathrm{RuTe}}_{2}$ & $\mathrm{CsBO}_{2}$ & $\mathrm{O}_{2}(\mathrm{~g})$ \\
\hline 298 & -1430144 & -794513 & -673 & -155723 & -303 & 527781 & 258298 & -152243 & -132144 & 919918 & 557 \\
\hline 300 & -1429716 & -794094 & -673000 & -155736 & -303413 & -527804 & -257952 & -152181 & -132083 & -919566 & -702593 \\
\hline 400 & -1407306 & -771771 & -655083 & -156599 & -304164 & -528995 & -239287 & -148803 & -128904 & -899757 & 3622 \\
\hline 500 & -1386118 & -749967 & -633614 & & -304907 & -530008 & -220855 & -145146 & -125707 & -879920 & 4291 \\
\hline 600 & -1366011 & -728544 & -612675 & -158342 & -305610 & -530814 & -202695 & -138849 & -122447 & -860160 & 700 \\
\hline 700 & -1346876 & -707424 & -592190 & -159137 & 306204 & -531393 & 4814 & 17 & -119114 & & 904 \\
\hline 800 & -1328632 & -686550 & -572070 & -159827 & -306657 & -531721 & -167216 & -125333 & -111846 & -821130 & 4941 \\
\hline 900 & -1311200 & -665874 & & & -3 & & & 49 & 187 & & 831 \\
\hline 1000 & -1294355 & -645199 & -532520 & -160570 & -306832 & -531372 & -132865 & -114104 & -94298 & -7 & -7 \\
\hline 1100 & 1277931 & 624368 & & -16 & -3 & & & & 266 & & 539 \\
\hline 1200 & -1262091 & -603566 & & -159664 & -305254 & -528966 & -99648 & -77217 & -76116 & -7 & 043 \\
\hline 1300 & -1247049 & -583017 & & -158962 & -304163 & -527388 & -83462 & -58942 & -65172 & -7 & 507 \\
\hline 1400 & -1232795 & -562727 & & -158176 & -302981 & -525648 & -67562 & -40776 & -47467 & -694936 & -670937 \\
\hline 1500 & -1218696 & -542071 & & -156675 & -301071 & -523132 & -51949 & -22707 & -29825 & -674906 & 331 \\
\hline 1600 & -1205251 & -521554 & & -154965 & -298919 & -520340 & -36620 & -4730 & -12249 & -655277 & 693 \\
\hline 1700 & -1192511 & -501240 & & -153112 & -296650 & -517351 & -21580 & 13151 & 5262 & -636017 & -648018 \\
\hline 1800 & -1180477 & -481132 & & -151117 & -294211 & -514160 & -6826 & 30947 & 22710 & -617099 & -640305 \\
\hline 1900 & -1169142 & -461231 & & -148981 & -291647 & -508751 & 7637 & 48658 & 40087 & -598506 & -632562 \\
\hline 2000 & -1158511 & -441548 & & -146702 & -288940 & -502329 & 21817 & 66287 & 57400 & -580207 & -624774 \\
\hline
\end{tabular}

The same sample has been used for enthalpy-of-solution measurements [10] from which we derive

Table 1

Gibbs energy of formation $\left(\mathrm{J} \mathrm{mol}^{-1}\right)$ 


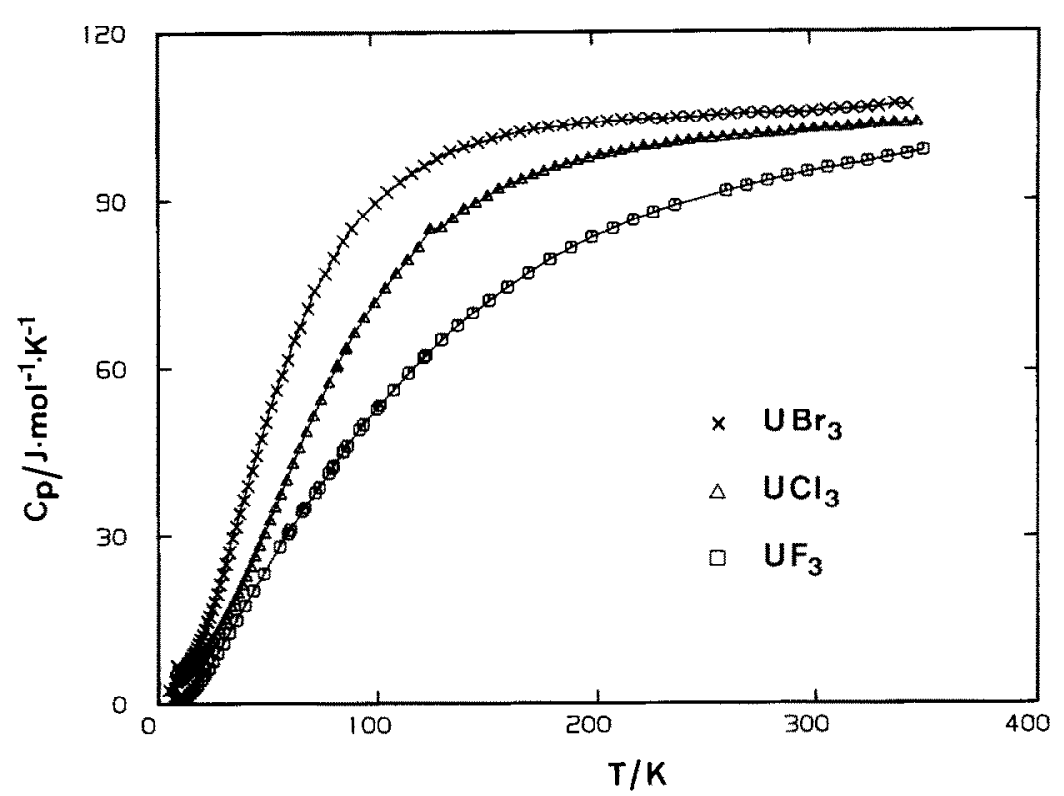

Fig. 1. The low-temperature heat capacity of $\mathrm{UF}_{3}, \mathrm{UCl}_{3}$, and $\mathrm{UBr}_{3}$.

$\Delta_{\mathrm{f}} H^{\circ}(298.15 \mathrm{~K})=-(862.1 \pm 3.2) \mathrm{kJ} \mathrm{mol}^{-1}$. This value differs slightly from the one assessed by Fuger et al. [8] and will be used here to calculate $\Delta_{\mathrm{f}} G^{\circ}$ values with the value at $298.15 \mathrm{~K}$ for $S^{\circ}$, and the enthalpy increment values [8], based on measurements by Ginnings and Corruccini (1947); the results are listed in table 1.

In this review we also include the thermochemical properties of $\mathrm{UBr}_{3}$, which are even less known than those of $\mathrm{UF}_{3}$ and $\mathrm{UCl}_{3}$. Our heat capacity measurements [7] give $C_{\mathrm{p}}^{\circ}(298.15 \mathrm{~K})=105.83 \mathrm{~J} \mathrm{~mol}^{-1} \mathrm{~K}^{-1}$ and $S^{\circ}(298.15 \mathrm{~K})=192.98 \mathrm{~J} \mathrm{~mol}^{-1} \mathrm{~K}^{-1}$ in fair agreement with the estimated values [8]. The assessed value for the enthalpy of formation, $\Delta_{\mathrm{f}} H^{\circ}(298.15 \mathrm{~K})=-(698.7 \pm$ $5.0) \mathrm{kJ} \mathrm{mol}^{-1}$ [8], has been used here to calculate the values for $\Delta_{\mathrm{f}} G^{\circ}(T)$ as listed in table 1 .

It should be noted that the trihalides of uranium have interesting magnetic behaviour at low temperatures $(<10 \mathrm{~K})$, exhibiting long-range anti-ferromagnetic ordering [11].

\section{The intermetallic compounds $\mathrm{UPd}_{3}, \mathrm{URh}_{3}$ and $\mathrm{URu}_{3}$}

The noble metals $\mathrm{Pd}, \mathrm{Rh}$ and $\mathrm{Ru}$ are formed in relatively high yield in a fast-breeder reactor where they can react with the fuel matrix to form inclusions of the composition ( $\mathrm{U}, \mathrm{Pu}) \mathrm{Me}_{3}$ with $\mathrm{Me}=\mathrm{Pd}, \mathrm{Rh}$ and $\mathrm{Ru}$. Bramman et al. [12] first reported the presence of these inclusions in irradiated oxide fuel. A quantitative analy-

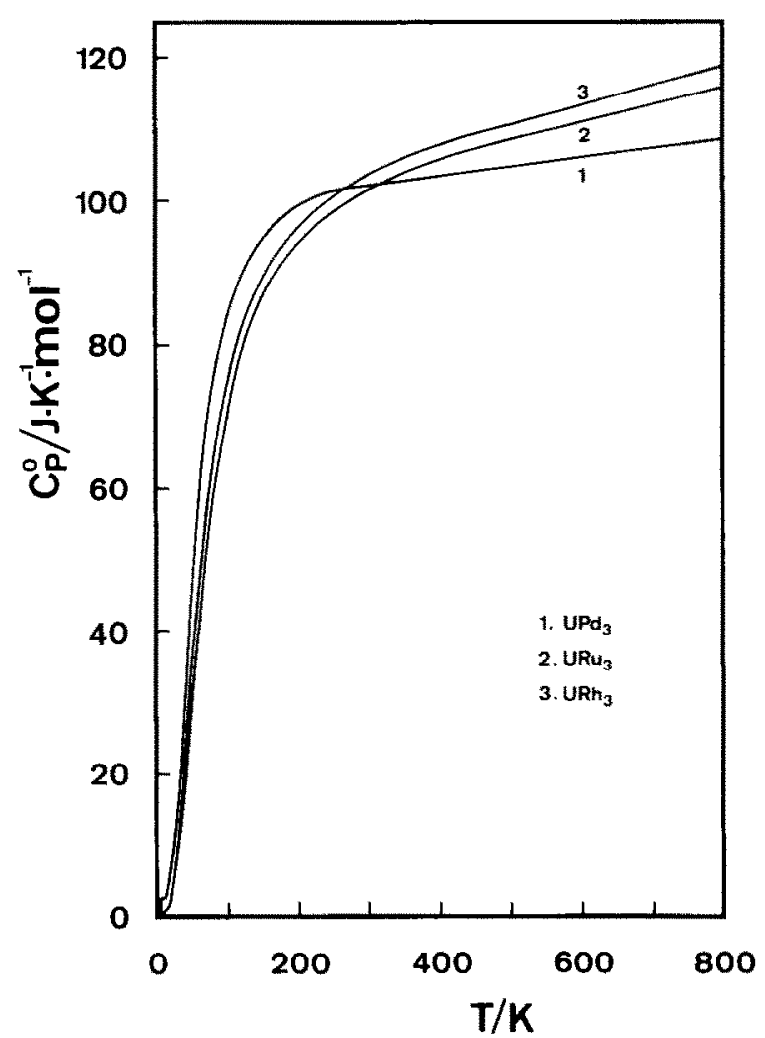

Fig. 2. The heat capacity of the cubic compounds URu $u_{3}$ and $\mathrm{URh}_{3}$, and the hexagonal compound $\mathrm{UPd}_{3}$. 
Table 2

Standard entropy and enthalpy of formation at $298.15 \mathrm{~K}$

\begin{tabular}{lll}
\hline Compound & $\begin{array}{l}S^{\circ} \\
\left(\mathrm{J} \mathrm{mol}^{-1} \mathrm{~K}^{-1}\right)\end{array}$ & $\begin{array}{l}\Delta_{\mathrm{f}} H^{\circ} \\
\left.(\mathrm{kJ} \mathrm{mol})^{-1}\right)\end{array}$ \\
\hline $\mathrm{UF}_{3}$ & 123.46 & -1502.1 \\
$\mathrm{UCl}_{3}$ & 158.14 & -862.1 \\
$\mathrm{UBr}_{3}$ & 192.98 & -698.7 \\
$\mathrm{URu}_{3}$ & 144.50 & $-153.2^{\mathrm{h}}$ \\
$\mathrm{URh}_{3}$ & 152.24 & -301.2 \\
$\mathrm{UPd}_{3}$ & 176.35 & -524 \\
$\mathrm{RuO}_{2}$ & 56.42 & -314.15 \\
$\mathrm{RuSe}_{2}$ & 80.09 & -162.1 \\
$\mathrm{RuTe}_{2}$ & {$[95]^{\mathrm{a}}$} & $-141.7^{\mathrm{b}}$ \\
$\mathrm{CsBO}_{2}$ & 105.38 & -976.8 \\
\hline
\end{tabular}

a) Estimated.

b) Recalculated.

sis of these precipitates gave the composition (in at \%); $\mathrm{U} 18, \mathrm{Pu}$ 8, Pd 59, Rh 15 and Ru 1 [13], which corresponds with $(\mathrm{U}, \mathrm{Pu}) \mathrm{Me}_{3}$, the $\mathrm{Pu} / \mathrm{U}+\mathrm{Pu}$ ratio being 0.31 . The inclusions are thus enriched in plutonium and cause, being insoluble in any solvent, Pu losses during the reprocessing.

The formation of these precipitates, even in mixed oxide fuel $(\mathrm{U}, \mathrm{Pu}) \mathrm{O}_{2}$, is surprising and indicates a high thermodynamic stability, as already predicted by Brewer [14].

The values of the Gibbs energies of formation of $\mathrm{URu}_{3}$ and $\mathrm{URh}_{3}$ have been measured by EMF measurements $[15,16]$ confirming their high thermodynamic stability. An evaluation of these measurements by thirdlaw analysis was, however, only possible after measurement of the heat capacities of these compounds $[17,18]$ (fig. 2), yielding the values given in table 2. The $\Delta_{\mathrm{f}} H^{\circ}$ values of the original publications have been recalculated to account for a redetermination of the enthalpy increment of Ru [19].

The enthalpy of formation of $\mathrm{UPd}_{3}$ has been measured by Wijbenga [20] using fluorine combustion calorimetry. The very negative value obtained, $-524 \mathrm{~kJ}$ $\mathrm{mol}^{-1}$, is consistent with the observation that the inclusions are rich in palladium.

The Gibbs energy of formation data, calculated from these measurements (table 1), enable us to calculate the conditions of formation of these intermetallic precipitates, in particular the oxygen potential of the mixed oxide fuel. To that purpose Wijbenga has estimated the $\Delta_{\mathrm{f}} G^{\circ}(2000 \mathrm{~K})$ values for $\mathrm{PuRu}_{3}, \mathrm{PuRh}_{3}$ and $\mathrm{PuPd}_{3}$ and obtained: $-226,-301$, and $-385 \mathrm{~kJ} \mathrm{~mol}^{-1}$, respectively [21].
When we take for the composition of the metallic inclusions: $\left(\mathrm{U}_{0.69} \mathrm{Pu}_{0.31}\right)\left[\mathrm{Ru}_{0.0133} \mathrm{Rh}_{0.20} \mathrm{Pd}_{0.7867}\right]_{3}$, as given by Kleykamp [13], we have to mix $0.69 \mathrm{~mol}$ $\mathrm{U}\left[\mathrm{Ru}_{0.0133} \mathrm{Rh}_{0.20} \mathbf{P d}_{0.7867}\right]_{3}$ with $0.31 \mathrm{~mol}$ of the corresponding plutonium compound. The solid solutions of $\mathrm{UMe}_{3}$ and $\mathrm{PuMe}_{3}$, in turn, can be made by mixing the appropriate amounts of $\mathrm{URu}_{3}, \mathrm{URh}_{3}$ and $\mathrm{UPd}_{3}$ or $\mathrm{PuRu}_{3}, \mathrm{PuRh}_{3}$, and $\mathrm{PuPd}_{3}$. To calculate the equilibrium compositions we assume that

$\Delta_{\text {mix }} H=0, \quad$ and $\Delta_{\text {mix }} S=-R \sum n_{i} \ln n_{i}$.

Thus,

$$
\begin{aligned}
\Delta_{\mathrm{f}} G^{\circ} & \left\{\mathrm{UMe}_{3}, 2000 \mathrm{~K}\right\} \\
= & 0.0133 \Delta G^{\circ}\left(\mathrm{URu}_{3}\right)+0.20 \Delta G^{\circ}\left(\mathrm{URh}_{3}\right) \\
& +0.7867 \Delta G^{\circ}\left(\mathrm{UPd}_{3}\right)-T \Delta S_{\text {mix }} .
\end{aligned}
$$

If we take the same composition for the corresponding plutonium solid solution, an identical expression for $\Delta_{\mathrm{f}} G^{\circ}\left(\mathrm{PuMe}_{3}, 2000 \mathrm{~K}\right)$ can be written. The values then obtained are -464.8 and $-375.5 \mathrm{~kJ} \mathrm{~mol}^{-1}$. respectively.

In order to calculate how the Pu-enrichment depends on the oxygen potential, we now have to mix $(1-x)$

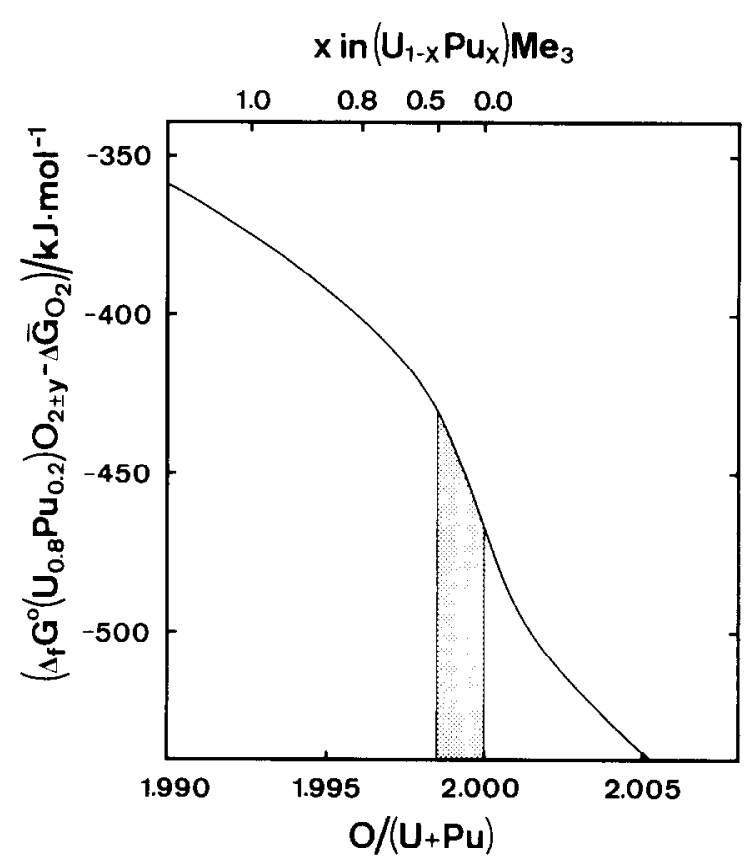

Fig. 3. The driving force for the plutonium enrichment, $\Delta_{\mathrm{f}} G^{\circ}(\mathrm{U}, \mathrm{Pu}) \mathrm{Me}_{3}-\Delta \bar{G}_{\mathrm{O}_{2}}$, as a function of the stoichiometry of the fuel. The shaded area indicates the compositions of the inclusions generally encountered. 
moles of the solid solution $\mathrm{UMe}_{3}$ with $x$-moles of the corresponding solid solution of plutonium:

$$
\begin{aligned}
\Delta_{\mathrm{f}} G^{\circ}(\mathrm{ss})= & (1-x) \Delta_{\mathrm{f}} G^{\circ}\left(\mathrm{UMe}_{3}\right)+x \Delta_{\mathrm{f}} G^{\circ}\left(\mathrm{PuMe}_{3}\right) \\
& +R T\{x \ln x+(1-x) \ln (1-x)\} .
\end{aligned}
$$

We now have the relationship:

$$
\Delta_{\mathrm{f}} G^{\circ}(\mathrm{ss}) \leqq \Delta_{\mathrm{f}} G^{\circ}(\mathrm{U}, \mathrm{Pu}) \mathrm{O}_{2}-R T \ln p_{O_{2}} \text {. }
$$

From fig. 3 it can be seen that the driving force for the plutonium enrichment in the intermetallic $(\mathrm{U}, \mathrm{Pu}) \mathrm{Me}_{3}$ inclusions is the oxygen potential in the fuel, and the difference between $\Delta_{\mathrm{f}} G^{\circ}\left(\mathrm{UMe}_{3}\right)$ and $\Delta_{\mathrm{f}} G^{\circ}\left(\mathrm{PuMe}_{3}\right)$. The conditions, needed for the formation of these intermetallic solid solutions, can be expected in failed fast breeder fuel, but are unlikely to be found in LWR fuel.

\section{Ruthenium chalcogenides}

Ruthenium, selenium and tellurium are important fission products for nuclear reactor safety studies. The fission yield of ruthenium is quite high $(\sim 8 \%$ of the fission product inventory), and its compounds with oxygen, selenium and tellurium may therefore play an important role in nuclear safety studies. Normally, ruthenium is a major constituent of the "white inclusions" in operating nuclear reactor fuel. The hexagonal white inclusions have been identified as a metallic solid solution of a number of transition metals, molybdenum being the other major component [22].
The formation of ruthenium dioxide in the $\mathrm{UO}_{2}$ matrix will probably not normally occur since the oxygen potential in operating nuclear fuel is generally too low [2]. However, under accident conditions in water-cooled reactor fuel, the equilibrium conditions change drastically as a result of the interaction with the coolant, and formation of solid $\mathrm{RuO}_{2}$ as well as the gaseous $\mathrm{RuO}_{3}$ and $\mathrm{RuO}_{4}$ molecules is possible. Accurate thermodynamic data for these compounds are needed to model the chemical processes occuring in nuclear accidents, especially the release as gaseous compounds to the containment building or, worse, the environment.

Up to now, a major problem in the evaluation of the $\mathrm{Ru}-\mathrm{O}$ system was the lack of an accurate experimental determination of the standard entropy of $\mathrm{RuO}_{2}(\mathrm{~s})$. Rard [23] derived $S^{\circ}(298.15 \mathrm{~K})=(52.2 \pm 8.7) \mathrm{J} \mathrm{mol}^{1} \mathrm{~K}^{1}$ from a second law analysis of EMF and decomposition measurements. Third-law analyses of vapour pressure measurements above $\mathrm{RuO}_{2}(\mathrm{~s})$, to give the enthalpies of formation of $\mathrm{RuO}_{3}(\mathrm{~g})$ and $\mathrm{RuO}_{4}(\mathrm{~g})$, as has been done by Rard, are consequently highly uncertain. We, therefore, decided to measure the low-temperature heat capacity of $\mathrm{RuO}_{2}$ by adiabatic calorimetry, yielding an accurate value for the standard entropy, $S^{\circ}(298.15 \mathrm{~K})$ $=(46.15 \pm 0.05) \mathrm{J} \mathrm{mol}^{-1} \mathrm{~K}^{-1}$ [24].

In addition, we performed drop calorimetric measurements covering the temperature range between the low-temperature heat capacity data and the recently reported EMF measurements [25]. The two sets of mea-

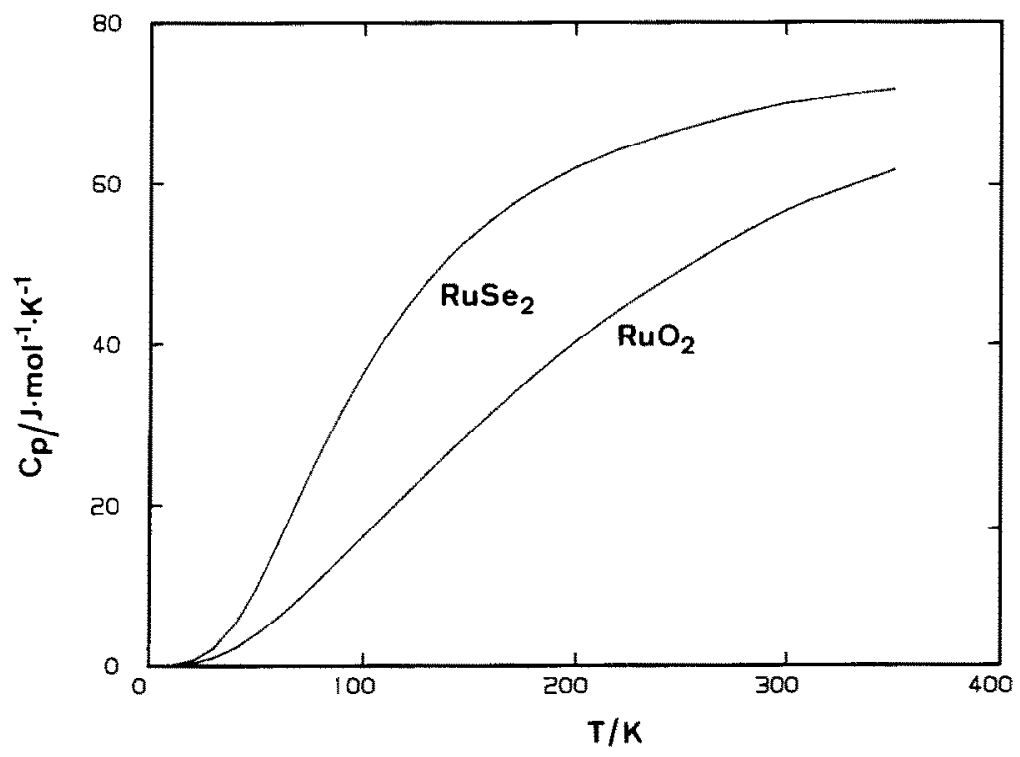

Fig. 4. The low-temperature heat capacity of $\mathrm{RuO}_{2}$ and $\mathrm{ReSe}_{2}$. 
surements join smoothly, and we thus obtain for $\mathrm{RuO}_{2}(\mathrm{~s}):$

$$
\begin{aligned}
& \left\{H^{\circ}(T)-H^{\circ}(298.15 \mathrm{~K})\right\} \\
& =53.644(T / \mathrm{K})+20.1905 \times 10^{-3}(T / \mathrm{K})^{2} \\
& \quad+8.2330 \times 10^{5}(T / \mathrm{K})^{-1}-20550 .
\end{aligned}
$$

It is now possible to analyse the EMF measurements by 'third law' (taking into account the redetermined enthalpy increment values for $R u$ [19]), to obtain for $\mathrm{RuO}_{2}$ the value $\Delta_{\mathrm{f}} H^{\circ}(298.15 \mathrm{~K})=-(314.15 \pm 0.5) \mathrm{kJ}$ $\mathrm{mol}^{-1}$. Finally, smoothed high-temperature functions can be calculated, including the Gibbs energy of formation (table 1).

Whereas $\mathrm{RuO}_{2}$ has the tetragonal rutile $\left(\mathrm{TiO}_{2}\right)$ structure, $\mathrm{RuSe}_{2}$ is cubic (pyrite-type) and isostructural with $\mathrm{RuTe}_{2}$. Low-temperature heat capacities have been measured in the adiabatic calorimetric cryostat as described elsewhere [26] (fig. 4). From the results the standard entropy of $\mathrm{RuSe}_{2}$ was derived to be $S^{\circ}(298.15 \mathrm{~K})=80.09 \mathrm{~J} \mathrm{~mol}^{-1} \mathrm{~K}^{-1}$. Enthalpy increments have been calculated, based on smoothed enthalpy values [26], to give:

$$
\begin{aligned}
&\left\{H^{\circ}(T)-H^{\circ}(298.15 \mathrm{~K})\right\} / \mathrm{J} \mathrm{mol}{ }^{1} \\
&= 68.224(T / \mathrm{K})+6.8365 \times 10^{-3}(T / \mathrm{K})^{2} \\
&+2.1516 \times 10^{5}(T / \mathrm{K})^{-1}-21670
\end{aligned}
$$

The data enable a 'third law' analysis of the decomposition pressures according to the equation:

$\operatorname{RuSe}_{2}(\mathrm{~s}) \rightarrow \mathrm{Ru}(\mathrm{s})+\mathrm{Se}_{2}(\mathrm{~g})$,

from which the value $\Delta_{\mathrm{f}} H^{\circ}(298.15 \mathrm{~K})=-(162.1 \pm 0.7)$ $\mathrm{kJ} \mathrm{mol}^{-1}$ was derived [26]. The $\Delta_{\mathrm{f}} G^{\circ}$ values, listed in table 1 , have been calculated using the auxiliary data for ruthenium and $\mathrm{Se}_{2}(\mathrm{~g})$.

For $\mathrm{RuTe}_{2}$ low-temperature heat capacities have not been reported, but an estimated entropy value can be derived from the entropy of $\mathrm{RuSe}_{2}$, and the trend in the entropies of the chalcogenides of $\mathrm{Mn}, \mathrm{Fe}$, and Pt. The value $S^{\circ}(298.15 \mathrm{~K})=(95 \pm 2.5) \mathrm{J} \mathrm{mol}^{-1} \mathrm{~K}^{-1}$ has thus been derived.

The entropy value derived enables us to evaluate the decomposition pressures of $\operatorname{RuTe}_{2}(\mathrm{~s})$, as measured by Svendsen [27], by third-law analysis, from which the value $\Delta_{\mathrm{f}} H^{\circ}(298.15 \mathrm{~K})=-(141.7 \pm 2.6) \mathrm{kJ} \mathrm{mol}^{-1}$ has been derived. The $\Delta_{\mathrm{f}} G^{\circ}$ values, calculated with these data and the drop calorimetric enthalpy increments measured by Svendsen [27], are listed in table 1.

\section{Cesium borate, $\mathrm{CsBO}_{2}$}

Light-water reactors contain large amounts of boron, either as $\mathrm{B}_{4} \mathrm{C}$ in control rods (BWR), or as $\mathrm{H}_{3} \mathrm{BO}_{3}$ dissolved in the primary coolant (PWR). In a severe reactor accident, when $\mathrm{H}_{3} \mathrm{BO}_{3}$ is released, $\mathrm{CsBO}_{2}$ is thought to be formed by the reaction with $\mathrm{CSI}_{\mathrm{SI}}$ according to:

$\mathrm{CsI}(\mathrm{g})+\mathrm{H}_{3} \mathrm{BO}_{3}(\mathrm{~g}) \rightarrow \mathrm{CsBO}_{2}(\mathrm{~g})+\mathrm{HI}(\mathrm{g})+\mathrm{H}_{2} \mathrm{O}(\mathrm{g})$.

The reaction is most extensive in the vapour phase, when CsI vapour is released into the boric-acid-rich steam atmosphere. The HI formed is very volatile and may thus contribute significantly to the transport of iodine.

Previous thermochemical calculations indicated that this reaction would not occur [28]. However, these calculations were based on the few data of $\mathrm{CsBO}_{2}$ that are available in literature. Khriplovitch et al. [29] measured the low-temperature heat capacities, and the NBS tables give a value for the enthalpy of formation of solid $\mathrm{CsBO}_{2}$ which has been derived from an unpublished thesis by Marakov [30]. Data for gaseous $\mathrm{CsBO}_{2}$ are few and not consistent. Since experiments at Winfrith [31] have shown that the reaction can proceed to the right, it was considered worthwhile to reinvestigate the thermodynamic properties of $\mathrm{CsBO}_{2}$.

The enthalpy of formation of solid $\mathrm{CsBO}_{2}$ has been determined by us by solution calorimetry, and we obtained $\Delta_{\mathrm{f}} H^{\circ}(298.15 \mathrm{~K})=-(976.8 \pm 0.9) \mathrm{kJ} \mathrm{mol}^{-1}$ [32]. This value differs slightly from the value selected by NBS.

Low-temperature heat capacities of $\mathrm{CsBO}_{2}(\mathrm{~s})$ have been measured by adiabatic calorimetry from 9 to 346 $\mathrm{K}$, and high-temperature enthalpy increments by drop calorimetry from 414 to $671 \mathrm{~K}$ to give [33]:

$S^{\circ}(298.15 \mathrm{~K})=105.38 \mathrm{~J} \mathrm{~mol}^{-1} \mathrm{~K}^{-1}$

and

$$
\begin{aligned}
\left\{H^{\circ}(T)-H^{\circ}(298.15 \mathrm{~K})\right\} / \mathrm{J} \mathrm{mol}^{-1} \\
=52.3364(T / \mathrm{K})+33.1614 \times 10^{-3}(T / \mathrm{K})^{2} \\
\quad+2.3296 \times 10^{5}(T / \mathrm{K})^{-1}-19333
\end{aligned}
$$

The low-temperature heat capacities differ considerably from the values reported by Khriplovich et al. [29].

The melting point of $\mathrm{CsBO}_{2}$ has been found, using DSC, to be $(989.7 \pm 0.3) \mathrm{K}$ and the enthalpy of fusion $(34.8 \pm 1.0) \mathrm{kJ} \mathrm{mol}^{-1}$ [33].

For gaseous $\mathrm{CsBO}_{2}$ the situation is worse. Data are available for the structure and vibrations of this molecule, and this enables us to calculate its thermodynamic 


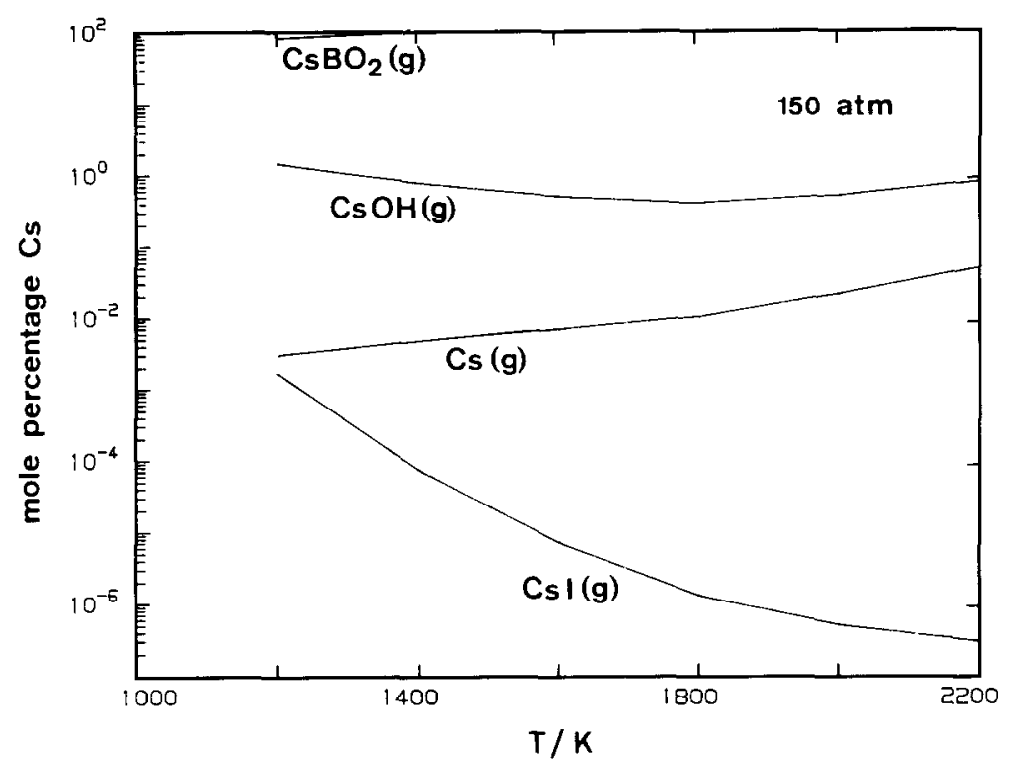

Fig. 5. The speciation of cesium in a boric acid-containing steam environment at 150 atm as a function of temperature.

functions. Discrepancies exist, however, in the enthalpy of formation of $\mathrm{CsBO}_{2}(\mathrm{~g})$. Vapour pressure measurements have been carried out by Gorokhov et al. [34], and Biswas and Mukerji [35]. A third-law analysis of these measurements, using the thermodynamic functions of solid and gaseous $\mathrm{CsBO}_{2}$ given here, yielded for the sublimation enthalpy at $298.15 \mathrm{~K}$ the values: 274.5 and $284.6 \mathrm{~kJ} \mathrm{~mol}^{-1}$, respectively. If we take the value $(280 \pm 5) \mathrm{kJ} \mathrm{mol}^{-1}$ as the mean, the enthalpy of formation of $\mathrm{CsBO}_{2}(\mathrm{~g})$ is $\Delta_{\mathrm{f}} H^{\circ}(298.15 \mathrm{~K})=-696.8 \mathrm{~kJ}$ $\mathrm{mol}^{-1}$. In view of the importance of the reaction in safety studies a redetermination of the vapour pressure measurements of $\mathrm{CsBO}_{2}$ seems to be desirable.

The thermodynamic properties of $\mathrm{CsBO}_{2}$ given here enable us to calculate the position of the equilibria under accident conditions. This calculation has been done at several temperatures between 1000 and $2200 \mathrm{~K}$, at pressures of 50 and $150 \mathrm{~atm}$, and $\mathrm{a} \mathrm{H}_{2} / \mathrm{H}_{2} \mathrm{O}$ ratio of 1.36 , using the SOLGASMIX programme. The elements, compounds and gaseous species which have been considered are $\mathrm{CsI}(\mathrm{s}), \mathrm{CsI}(\mathrm{g}), \mathrm{Cs}_{2} \mathrm{I}_{2}(\mathrm{~g}), \mathrm{I}_{2}(\mathrm{~g}), \mathrm{I}(\mathrm{g}), \mathrm{Cs}(\mathrm{g})$, $\mathrm{Cs}_{2}(\mathrm{~g}), \mathrm{CsOH}(\mathrm{g}),(\mathrm{CsOH})_{2}(\mathrm{~g}), \mathrm{B}(\mathrm{s}), \mathrm{B}_{2} \mathrm{O}_{3}(\mathrm{~s}), \mathrm{H}_{3} \mathrm{BO}_{3}(\mathrm{~g})$, $\mathrm{HBO}_{2}(\mathrm{~g}), \mathrm{CsBO}_{2}(l), \mathrm{CsBO}_{2}(\mathrm{~g}), \mathrm{H}_{2}(\mathrm{~g}), \mathrm{O}_{2}(\mathrm{~g}), \mathrm{H}_{2} \mathrm{O}(\mathrm{g})$. Additionally, the condensed phases $\mathrm{UO}_{2}$ and $\mathrm{Cs}_{2} \mathrm{UO}_{3.5}$ were included. The data for all these phases have been taken from a recent assessment [36].

In fig. 5 we give some results of a calculation of the speciation at the given conditions from which it is concluded that cesium is mainly divided over the mole- cules $\mathrm{CsBO}_{2}(\mathrm{~g}), \mathrm{CsOH}(\mathrm{g})$, and (to a minor extent) $(\mathrm{CsOH})_{2}(\mathrm{~g})$. Iodine is almost entirely present as $\mathrm{HI}(\mathrm{g})$; the mole fraction of all other cesium or iodine-containing molecules is $<0.01$. This means that the two competing reactions are:

$$
\begin{aligned}
& \mathrm{CsI}(\mathrm{g})+\mathrm{H}_{2} \mathrm{O}(\mathrm{g}) \rightarrow \mathrm{CsOH}(\mathrm{g})+\mathrm{HI}(\mathrm{g}), \\
& \mathrm{CsI}(\mathrm{g})+\mathrm{H}_{3} \mathrm{BO}_{3}(\mathrm{~g}) \rightarrow \mathrm{CsBO}_{2}(\mathrm{~g})+\mathrm{HI}(\mathrm{g})+\mathrm{H}_{2} \mathrm{O}(\mathrm{g}),
\end{aligned}
$$

$\mathrm{CsBO}_{2}(\mathrm{~g})$ being the predominant species.

The ratio $\mathrm{H}_{3} \mathrm{BO}_{3}(\mathrm{~g}) / \mathrm{HBO}_{2}(\mathrm{~g})$ depends on the temperature and is $\approx 1$ around $1700 \mathrm{~K}$; at lower temperatures $\mathrm{H}_{3} \mathrm{BO}_{3}(\mathrm{~g})$ is the predominant species. It should be noted that the equilibria depend on pressure: at $1 \mathrm{~atm}$ nearly all cesium is present as $\mathrm{CsBO}_{2}(\mathrm{~g})$.

\section{Conclusions}

In the preceding examples we have tried to show the importance of having accurate thermochemical data for the calculation and prediction of the complex chemical equilibria that occur in the various parts of the fuel cycle. Especially for the study of the chemical changes which occur during accident conditions at temperatures $>1000 \mathrm{~K}$, where many gaseous species will play a role in the transport of the fission products, more and more accurate data are needed. For instance, experimental data for the gaseous hydroxides of most elements are unknown or unreliable, and, as a consequence, com- 
putcr codes have to use estimated values in most cases. Even more serious is the almost complete lack of information on important groups of compounds, like the tellurides and the volatile ternary oxide species, such as cesium molybdate and ruthenate, which could be responsible for the transport of molybdenum and ruthenium. These gaps can only be filled in by more, and more accurate experimental thermochemical investigations.

\section{Acknowledgement}

The financial support of the US Nuclear Regulatory Commission, Washington, DC, is gratefully acknowledged.

\section{References}

[1] F.D. Rossini, Pure Appl. Chem. 8 (1964) 95.

[2] E.H.P. Cordfunke and R.J.M. Konings, J. Nucl. Mater. 152 (1988) 301.

[3] E.F. Westrum, Jr., G.T. Furukawa and J.P. McCullough, in: Experimental Thermodynamics, Eds. J.P. McCullough and D.W. Scott, Vol. I (Butterworth, London, 1968).

[4] E.H.P. Cordfunke, R.P. Muis and G. Prins, J. Chem. Thermodyn. 11 (1979) 819.

[5] E.H.P. Cordfunke, W. Ouwelies and G. Prins, J. Chem. Thermodyn. 7 (1985) 1137.

[6] E.H.P. Cordfunke and R.J.M. Konings, Thermochim. Acta 129 (1988) 63.

[7] E.H.P. Cordfunke and E.F. Westrum, Jr., to be published.

[8] J. Fuger, V.B. Parker, W.N. Hubbard and F.L. Oetting, The Chemical Thermodynamics of Actinide Elements and Compounds, Part 8, The Actinide Halides (IAEA, Vienna, 1983).

[9] I. Johnson, J. Nucl. Mater. 154 (1988) 169.

[10] E.H.P. Cordfunke, W. Ouweltjes and G. Prins, J. Chem. Thermodyn. 14 (1982) 495.

[11] A. Murasik, P. Fischer, A. Furrer and W. Szczepaniak, J. Phys. C: Solid State Phys. 18 (1985) 2909.

[12] J.I. Bramman, R.M. Sharpe, D. Thom and G. Yates, J, Nucl. Mater, 25 (1968) 201.

[13] H. Kleykamp, in: Proc. of a Panel on Behaviour and
Chemical State of Irradiated Ceramic Fuels, Vienna. 1972 (IAEA, Vienna, 1974) p. 157.

[14] L. Brewer, Acta Metall. 15 (1967) 553.

[15] H. Holleck and H. Kleykamp, Z. Metalk. 66 (1975) 298.

[16] G. Wijbenga and E.H.P. Cordfunke, J. Chem. Thermodyn. 14 (1982) 409.

[17] E.H.P. Cordfunke, R.P. Muis, G. Wijbenga, R. Burriel, M. To, H. Zainel and E.F. Westrum, Jr. J. Chem. Thermodyn. 17 (1985) 1035

[18] R. Burriel, M. To, H. Zainel, E.F. Westrum, Jr, E.H.P. Cordfunke, R.P. Muis and G. Wijbenga, J. Chem. Thermodyn. 20 (1988) 815.

[19] E.H.P. Cordfunke and R.J.M. Konings, Thermochim. Acta 139 (1989) 99.

[20] G. Wijbenga, J. Chem. Thermodyn. 14 (1982) 483.

[21] G. Wijbenga, Thesis, University of Amsterdam (1981).

[22] H. Kleykamp, J.O. Paschoal, R. Pejsa and F. Thümmler, J. Nucl. Mater. 130 (1985) 426.

[23] J.A. Rard, Chem. Rev. 85 (1985) 1.

[24] E.H.P. Cordfunke, R.J.M. Konings, E.F. Westrum, Jr. and R. Shaviv, J. Phys. Chem. Solids 50 (1989) 429.

[25] E.H.P. Cordfunke and R.J.M. Konings, Thermochim. Acta $129(1988) 63$.

[26] S.R. Svendsen, F. Gronvold and E.F. Westrum, Jr, I. Chem. Thermodyn. 19 (1987) 1009.

[27] S.R. Svendsen, J. Chem. Thermodyn. 9 (1977) 789.

[28] R.A. Sallach and R.M. Elrick, in: Proc. Conf. on Fission Product Behaviour and Source Term Research, Snowbird. 1984.

[29] L.M. Khriplovich, A.P. Popov and I.E. Paukov, Zhur. Fiz. Khim. 50 (1976) 567.

[30] A.V. Marakov, Thesis, University of Moscow, date of publication unknown.

[31] B.R. Bowsher and S. Dickinson, AEEW-report R2102 (1986).

[32] R.J.M. Konings, E.H.P. Cordfunke and W. Ouwelties, J. Chem. Thermodyn. 19 (1987) 201.

[33] E.H.P. Cordfunke, R.J.M. Konings and E.F. Westrum, Jr., Thermochim. Acta 128 (1988) 31.

[34] L.N. Gorokhov, A.V. Gusarov, A.V. Marakov and O.T. Nikitin, Tepl. Vys. Temp. 9 (1971) 1173.

[35] S.R. Biswas and J. Mukerji, J. Chem. Eng. Data 16 (1971) 336.

[36] E.H.P. Cordfunke, R.J.M. Konings, P.E. Potter, G. Prins and M.H. Rand, Thermochemical Data for Reactor Materials and Fission Products (Elsevier, Amsterdam, 1989) to be published. 